\title{
Folliculotropic mycosis fungoides coexisting with pancreatic neuroendocrine tumour
}

\section{Ziarniniak grzybiasty folikulotropowy współistniejący z guzem neuroendokrynnym trzustki}

Julia Nowowiejska, Anna Baran, Iwona Flisiak

Department of Dermatology and Venereology, Medical University of Bialystok, Poland

Klinika Dermatologii i Wenerologii Uniwersytetu Medycznego w Białymstoku, Polska

Dermatol Rev/Przegl Dermatol 2018, 105, 746-752 DOI: https://doi.org/I0.5।|4/dr.2018.80844

\author{
CORRESPONDING AUTHOR/ \\ ADRES DO KORESPONDENCJI: \\ lek. Julia Nowowiejska \\ Klinika Dermatologii \\ i Wenerologii \\ Uniwersytet Medyczny \\ w Białymstoku \\ ul. Żurawia 14 \\ 15-540, Białystok, Poland \\ tel.: +48607130193 \\ e-mail: julka.nw@gmail.com
}

\begin{abstract}
Introduction. Folliculotropic mycosis fungoides is one of the mycosis fungoides variants with neoplastic T-helper lymphocytes infiltrating hair follicles. It often affects head and neck with a variety of lesions.

Objective. To present a patient with folliculotropic mycosis fungoides and coexisting pancreatic neuroendocrine tumour.

Case report. A 63-year-old male with a 15-year history of erythematous-papular exfoliating lesions with pruritus has been treated in ambulatory care. After 10 years he was referred to the hospital. Lesional biopsy was non-specific at that time. Five years later folliculotropic mycosis fungoides was diagnosed on the basis of clinical and histopathological features. The patient underwent Re-PUVA therapy with no improvement, and then methotrexate was introduced. At that time the diagnosis of coexisting pancreatic neuroendocrine tumour was made.

Conclusions. Folliculotropic mycosis fungoides is a rare type of cutaneous T-cell lymphoma with a 5-year survival rate reaching $80 \%$. The presented case highlights the possibility of atypical clinical features of the diseases and coexistence of other neoplastic comorbidities.
\end{abstract}

\section{STRESZCZENIE}

Wprowadzenie. Folikulotropowy ziarniniak grzybiasty jest jedną z odmian ziarniniaka grzybiastego, charakteryzującą się nowotworowymi naciekami mieszków włosowych z limfocytów T. Różnopostaciowe zmiany skórne często zajmują skórę głowy i szyi.

Cel pracy. Przedstawienie pacjenta $\mathrm{z}$ folikulotropowym ziarniniakiem grzybiastym i współistniejącym guzem neuroendokrynnym trzustki.

Opis przypadku. Mężczyzna 63-letni z 15-letnim wywiadem zmian rumieniowo-grudkowych ze złuszczaniem i towarzyszącym świądem, leczony ambulatoryjnie, został skierowany do Kliniki po raz pierwszy po 10 latach od pierwszych objawów. Obraz mikroskopowy pobranego wówczas wycinka skórnego był niecharakterystyczny. Podczas ponownej hospitalizacji, 5 lat później zdiagnozowano folikulotropowego ziarniniaka grzybiastego na podstawie obrazu klinicznego i mikroskopowego. Zastosowano terapię Re-PUVA, nie uzyskując poprawy klinicznej, a następnie metotreksat. W czasie diagnostyki dodatkowo ustalono wstępne rozpoznanie guza neuroendokrynnego trzustki. 
Wnioski. Rzadko spotykana odmiana folikulotropowa jest wariantem ziarniniaka grzybiastego, w którym 5-letnie przeżycie sięga $80 \%$. Przedstawiony przypadek zwraca uwagę na możliwość występowania nietypowego obrazu zmian skórnych, bez zajęcia skóry twarzy, oraz możliwość współistnienia nowotworu.

Key words: mycosis fungoides, pancreatic tumour, lymphoma.

Słowa kluczowe: ziarniniak grzybiasty, guz trzustki, chłoniak.

\section{INTRODUCTION}

Primary cutaneous T-cell lymphomas (PCTCL) are rare lymphoproliferative diseases and constitute about $65 \%$ of all primary cutaneous lymphomas [1, 2]. Mycosis fungoides (MF) is the most common one as it occurs with frequency of about $0.5-1 / 100,000$, and is twice more likely in women than in men [1]. One of the variants is folliculotropic MF, which constitutes less than $10 \%$ of all MF cases, and $4 \%$ of all PCTCL cases. It is characterized by hair follicle infiltration with atypical T-helper lymphocytes; the epidermis is usually spared [2-5]. Skin lesions, which usually affect the head and neck, may be varied: acne-like (comedos, papulae, nodules, and cysts), milium-like, with co-existing alopecia and infiltrative foci in the eyebrows [3, 6-9]. They are usually accompanied by severe pruritus $[9,10]$. The folliculotropic type most often occurs in adults, with males predominating (4 or 5 times more often) $[9,11,12]$. Upon microscopic examination the following are observed: hair follicle infiltrations from small, medium, and sometimes large cerebriform T-helper lymphocytes, with or without co-existing follicular mucinosis $[3,8,13,14]$. Immunohistochemical examination corresponds with a classic MF type: CD3+, CD4+, CD7-, with the CD4:CD8 infiltration ratio higher than $6: 1$. Involvement of lymph nodes and peripheral blood is occasional, at least in early stages [11]. Internal organs are hardly ever involved, however, there are reports indicating lesions within lungs or liver [15]. Concurrent involvement of lymph nodes or another hematologic neoplasm are also possible [12].

\section{OBJECTIVE}

To present a patient with folliculotropic MF who was also diagnosed with a pancreatic neuroendocrine tumor.

\section{CASE REPORT}

A 63-year-old male patient was hospitalized at Dermatology Department several times due to ery-

\section{WPROWADZENIE}

Pierwotne skórne chłoniaki T-komórkowe (primary cutaneous T-cell lymphomas - PCTCL) należą do rzadkich schorzeń limfoproliferacyjnych i stanowią ok. $65 \%$ wszystkich chłoniaków pierwotnie skórnych $[1,2]$. Najczęstszym z nich jest ziarniniak grzybiasty (mycosis fungoides - MF), który występuje z częstością ok. 0,5-1/100 000, dwukrotnie częściej u mężczyzn niż u kobiet [1]. Jedną z jego wielu odmian jest postać folikulotropowa, która stanowi mniej niż 10\% wszystkich przypadków MF, natomiast 4\% wszystkich PCTCL. Charakteryzuje się obecnością nacieku złożonego $\mathrm{z}$ atypowych limfocytów T pomocniczych dotyczącego mieszków włosowych, zwykle z oszczędzeniem naskórka [2-5]. Zmiany skórne, najczęściej zajmujące okolice głowy i szyi, mogą być bardzo różnorodne - trądzikopodobne (zaskórniki, grudki, guzki, cysty), prosakowate, ze współistniejącym łysieniem i naciekowymi ogniskami w brwiach [3, 6-9]. Zazwyczaj towarzyszy im silny świąd $[9,10]$. Postać folikulotropowa najczęściej występuje u osób dorosłych, z przewagą płci męskiej (4-5 razy częściej) [9, 11, 12]. W obrazie mikroskopowym obserwuje się nacieki mieszków włosowych złożone z małych, średnich, a czasem również dużych mózgokształtnych limfocytów T pomocniczych, niekiedy ze współistniejącą mucynozą mieszkową $[3,8,13,14]$. Badanie immunohistochemiczne odpowiada klasycznej postaci MF: CD3+, CD4+, CD7-, ze stosunkiem CD4 : CD8 w nacieku wyższym niż 6 : 1. Zajęcie węzłów chłonnych i krwi obwodowej spotykane jest sporadycznie, przynajmniej we wczesnych stadiach [11]. Bardzo rzadko obserwuje się zajęcie narządów wewnętrznych, istnieją jednak doniesienia o zmianach w obrębie płuc i wątroby [15]. Możliwe jest jednoczesne zajęcie węzłów chłonnych lub występowanie innego nowotworu hematologicznego [12].

\section{CEL PRACY}

Przedstawienie przypadku pacjenta $\mathrm{z}$ odmianą folikulotropową MF, u którego zdiagnozowano również guz trzustki. 
thematous-papular exfoliating lesions and accompanying pruritus that persisted for 15 years. Periodically, the patient underwent ambulatory treatment with glucocorticosteroid ointments that resulted in a temporary improvement. After 10 years he was referred to the Department for the first time in order to undergo diagnostics and treatment (fig. 1). A biopsy section taken from the infiltrative and papular lesions found on the arm skin showed a non-specific microscopic image; however, mycosis fungoides was ruled out. During the subsequent five years new disease foci appeared, mainly on the skin of upper and lower limbs. The patient was referred to the Department again. Upon admission, quite numerous erythematous and infiltrative foci with perifollicular papulae (upon removal, a whitish mass was evacuated) were observed on the skin of buttocks as well as upper and lower limbs. Surface of the skin lesions was hard, infiltrated, and with presence of follicular keratosis and exfoliation (fig. 2). A biopsy was taken from the skin lesion. Treatment included clobetasol, betamethasone, and a $10 \%$ ichthyol ointment. When the patient was discharged, a histopathological test result arrived - the microscopic image and immunophenotype of the infiltration cells (CD3+, CD4+, CD8-, CD20-, Ki67+) corresponded to folliculotropic mycosis fungoides; mucin stain was positive.

The patient was admitted to the Department again after a month in order to deepen diagnostics and treatment. Abdominal cavity ultrasound did not show any significant deviations from the norm. After a consultation with a haematologist, a Re-PUVA therapy was commenced (methoxalen $40 \mathrm{mg}$, acitretin $0.5 \mathrm{mg} / \mathrm{kg}$ body weight/day). Glucocorticosteroid ointments and emollients continued to be used in topical treatment. The patient was discharged home with a recommendation to continue Re-PUVA at the Outpatient Clinic of Dermatology and Haematology. Visible clinical improvements were not observed

\section{OPIS PRZYPADKU}

Mężczyzna 63-letni był hospitalizowany w Klinice Dermatologii kilkukrotnie z powodu utrzymujących się od 15 lat zmian rumieniowo-grudkowych ze złuszczaniem i towarzyszącym świądem. Pacjent był okresowo leczony ambulatoryjnie maściami glikokortykosteroidowymi z przejściową poprawą. Po 10 latach po raz pierwszy został skierowany do Kliniki w celu diagnostyki i leczenia (ryc. 1). W pobranym wówczas wycinku ze zmian naciekowo-grudkowych ze skóry ramienia obraz mikroskopowy był niecharakterystyczny, wykluczono jednak MF. W ciągu kolejnych 5 lat pojawiały się nowe ogniska chorobowe, głównie na skórze kończyn górnych i dolnych. Pacjenta ponownie skierowano do Kliniki. Przy przyjęciu w obrębie skóry pośladków oraz kończyn górnych i dolnych obserwowano dość liczne ogniska rumieniowo-naciekowe z grudkami przymieszkowymi. Po uciśnięciu grudek dochodziło do ewakuacji białawej masy. Powierzchnia zmian skórnych była twarda, nacieczona, z obecnością rogowacenia mieszkowego i złuszczania (ryc. 2). Pobrano wycinek ze zmiany skórnej. W leczeniu zastosowano klobetazol, betametazon i 10\% maść ichtiolową. Po wypisaniu pacjenta otrzymano wynik badania histopatologicznego - obraz mikroskopowy i immunofenotyp komórek nacieku (CD3+, CD4+, CD8-, CD20-, Ki67+) odpowiadały ziarniniakowi grzybiastemu mieszkowemu, a barwienie na mucynę było dodatnie.

Pacjent został przyjęty ponownie do Kliniki miesiąc później w celu pogłębienia diagnostyki i leczenia. W badaniu ultrasonograficznym jamy brzusznej nie wykazano żadnych istotnych odchyleń od stanu prawidłowego. Po konsultacji z hematologiem rozpoczęto terapię Re-PUVA (metoksalen w dawce 40 mg, acytretyna w dawce $0,5 \mathrm{mg} / \mathrm{kg}$ m.c./ dobę). W leczeniu miejscowym kontynuowano stosowanie maści glikokortykosteroidowych i emolientów. Pacjenta wypisano do domu z zaleceniem kontynuacji leczenia Re-PUVA w przyklinicznej poradni dermatologicznej oraz kon-

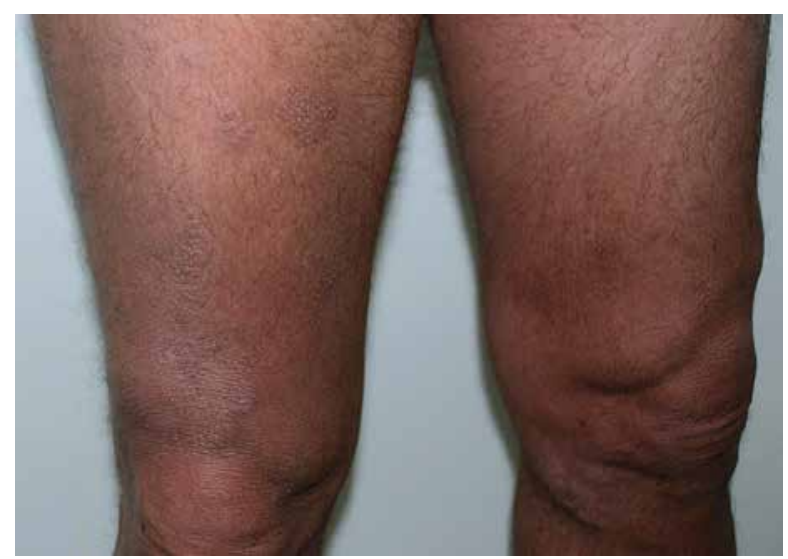

Figure I. Erythematous infiltrated lesions with follicular papulae over the skin of both lower limbs

Rycina I. Ogniska rumieniowo-naciekowe z grudkami przymieszkowymi w obrębie skóry obu kończyn dolnych 


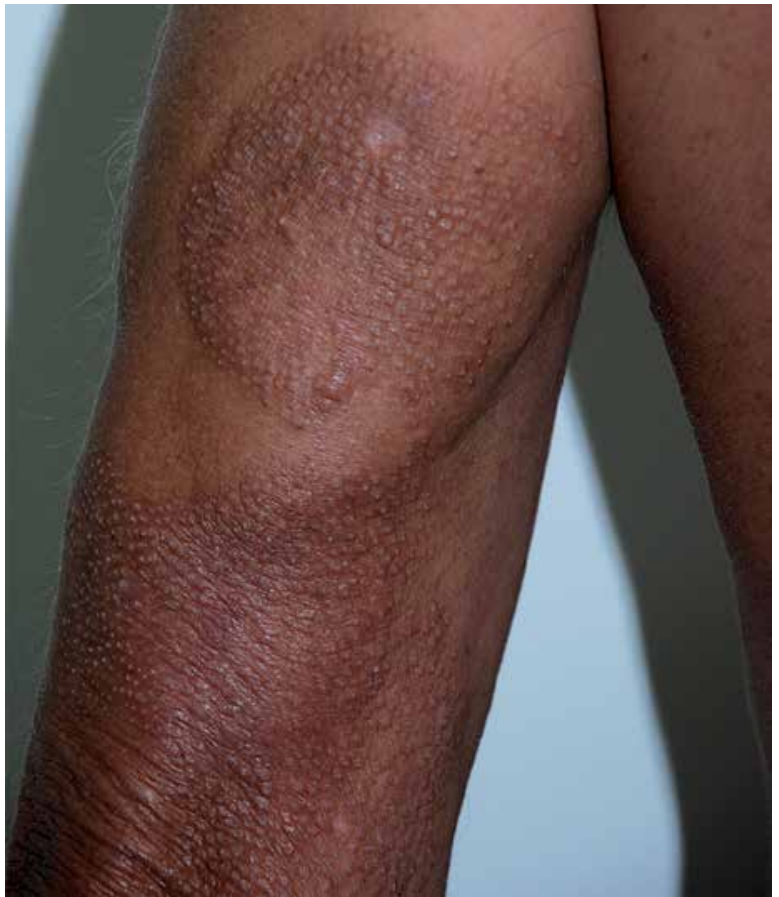

Figure 2. Erythematous infiltrated lesions with follicular papulae on the skin of the left arm

Rycina 2. Ogniska rumieniowo-naciekowe z grudkami przymieszkowymi w obrębie skóry ramienia lewego

during and after the therapy; single new disease foci appeared and were accompanied with pruritus. After six months from the last hospitalization, the patient was admitted to the Department again in order to modify his treatment. Upon admission, quite numerous erythematous and infiltrative lesions with perifollicular papulae were present on the skin of upper and lower limbs; lymph nodes were impalpable (fig. 3). Abdominal cavity computed tomography revealed an area in the head of pancreas described as a post-inflammatory lesion that should be controlled. Having consulted an oncologist, the patient was started on oral methotrexate in the dose of $20 \mathrm{mg} /$ week and folic acid in the dose of $15 \mathrm{mg} /$ week. Then, the patient was hospitalized at the Gastroenterology Department in order to diagnose focal lesions in the pancreas. An endoscopic ultrasound was performed during which a hypoechogenic focal lesion was revealed in the lower part of the head with calcification inside; moreover, a fine-needle aspiration biopsy of the lesion was performed. A pancreatic neuroendocrine tumour was initially diagnosed. The patient was referred to Oncology Centre in order to determine further diagnostics and therapies. Unfortunately, at the moment there is no contact with the patient, and consequently, no information with regard to his condition since the last hospitalization. He has not reported to the Outpatient Clinic of Dermatology again.

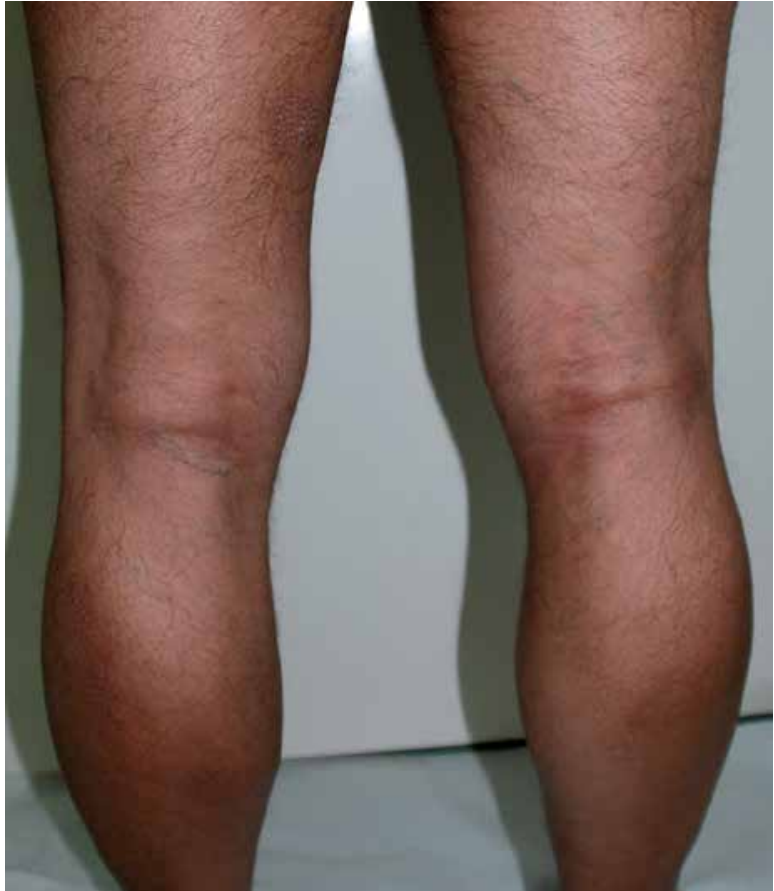

Figure 3. Erythematous infiltrated lesions with follicular papulae on the lower limbs persisting despite the Re-PUVA treatment

Rycina 3. Utrzymujące się pomimo leczenia Re-PUVA ogniska rumieniowo-naciekowe z przymieszkowymi grudkami na kończynach dolnych

troli w poradni hematologicznej. Nie obserwowano wyraźnej poprawy klinicznej w trakcie terapii ani po jej zakończeniu. Pojawiały się pojedyncze nowe ogniska chorobowe, którym towarzyszył świąd. Po 6 miesiącach od ostatniej hospitalizacji pacjenta ponownie przyjęto do Kliniki w celu modyfikacji leczenia. Przy przyjęciu obecne były dość liczne zmiany rumieniowo-naciekowe z grudkami przymieszkowymi na skórze kończyn górnych i dolnych, a węzły chłonne dostępne badaniem palpacyjnym były niewyczuwalne (ryc. 3). W badaniu metodą tomografii komputerowej jamy brzusznej w rzucie głowy trzustki stwierdzono obszar opisywany jako prawdopodobna zmiana pozapalna, zalecono kontrolę. Po konsultacji z onkologiem włączono metotreksat doustnie w dawce $20 \mathrm{mg} /$ tydzień oraz suplementację kwasem foliowym $15 \mathrm{mg} /$ tydzień. Pacjent był następnie hospitalizowany w Klinice Gastroenterologii $w$ celu diagnostyki zmian ogniskowych w trzustce. Wykonano endoskopową ultrasonografię, podczas której stwierdzono hipoechogenną zmianę ogniskową w dolnej części głowy, ze zwapnieniami wewnątrz. Wykonano także biopsję aspiracyjną cienkoigłową zmiany. Ustalono wstępne rozpoznanie guza neuroendokrynnego trzustki. Pacjenta skierowano do Centrum Onkologii w celu ustalenia dalszego postępowania diagnostyczno-terapeutycznego. Niestety od czasu ostatniej hospitalizacji nie ma kontaktu z pacjentem i informacji o jego stanie zdrowia. Nie zgłosił się więcej do przyklinicznej poradni dermatologicznej. 


\section{DISCUSSION}

Due to affinity to hair follicles, skin lesions in folliculotropic mycosis fungoides usually involve areas abundant in pilosebaceous units, i.e. head, neck, and upper part of chest, and take the shape of various exanthemas originating in these units [10]. Most often they include perifollicular papulae as well as erythematous and infiltrative lesions, then, acne-like lesions, cysts and milia, and least commonly alopecia within head and eyebrow skin [16]. The mechanism of folliculotropism is not fully known. It is suspected that it may be dependent on T-cell specific surface antigens or anomalies within follicular epithelium [10]. It should be noted that despite such a typical site for folliculotropic type described in the literature, the first lesions appeared on our patient's lower (including buttocks) and upper limbs. This different site is less often described in case reports, however, there are cases when first exanthemas appeared on the abdomen [5]. A rare phenomenon, which was observed in our patient, is mucinorrhea, i.e. a discharge of mucinous fluid from compressed follicles [11]. Occasionally, single disease foci are found, however, more often the disease manifests itself as widespread lesions covering over $10 \%$ of skin surface - as it was the case with our patient. Skin involvement in the form of erythroderma is similarly rare [4].

It is difficult to make a diagnosis, despite having performed a histopathological examination of a lesion section, because microscopic image remains non-specific for a long time. Consequently, it should be considered to repeat biopsies till diagnostic material is obtained and the final diagnosis is established [10]. A biopsy section should be taken from the most infiltrated sites [17]. It is worth remembering that a variety of skin lesions observed in the folliculotropic type translate into a variety of microscopic images during histopathological examination of different section or even within one section [11]. Scientific reports emphasize the importance of differentiating between the folliculotropic type and the classic, most common MF type. It is associated with differences in prognoses and responses to applied treatment, because both types are different with regard to reactions to various therapeutic methods understood as, first and foremost, efficacy of a therapy directed towards skin in classic MF and its lack in folliculotropic type [10]. Thus, in case of our patient, Re-PUVA therapy was used first, and then, as there was only a slight improvement, methotrexate was introduced.

Another important matter is $\mathrm{MF}^{\prime}$ s connection to other neoplasms. Literature does not contain many reports on this topic. It is observed that patients who had MF are at increased risk of developing especially: Hodgkin's lymphoma, chronic leukaemia or lung

\section{OMÓWIENIE}

Ze względu na powinowactwo do mieszków włosowych zmiany skórne w przebiegu ziarniniaka grzybiastego folikulotropowego zwykle zajmują okolice, w których obficie występują jednostki włosowo-łojowe, takie jak głowa, szyja i górna część klatki piersiowej. Mogą przyjmować postać różnych wykwitów wywodzących się z tych jednostek [10]. Najczęściej są to grudki przymieszkowe i zmiany rumieniowo-naciekowe, następnie zmiany trądzikopodobne, cysty i prosaki, i jeszcze rzadziej łysienie w obrębie skóry głowy i brwi [16]. Mechanizm folikulotropizmu nie jest do końca poznany. Podejrzewa się, że może to zależeć od swoistych antygenów powierzchniowych komórek T lub anomalii w obrębie nabłonka mieszków [10]. Na uwage zasługuje fakt, że mimo tak typowej dla postaci folikulotropowej lokalizacji, opisywanej w piśmiennictwie, $u$ przedstawionego pacjenta pierwsze zmiany pojawiły się na kończynach dolnych (w tym na pośladkach) i górnych. Taka odmienna lokalizacja jest rzadziej opisywana w pracach kazuistycznych, można jednak doszukać się przypadków, w których pierwsze wykwity pojawiały się na brzuchu [5]. Rzadko spotykanym zjawiskiem, które jednak udało się zaobserwować u opisywanego chorego, jest mucinorrhea, polegająca na wycieku śluzowej substancji z uciśniętych mieszków [11]. Sporadycznie stwierdza się pojedyncze ogniska chorobowe. Częściej choroba ma postać bardziej rozległych zmian, obejmujących ponad $10 \%$ powierzchni skóry - podobnie było w opisywanym przypadku. Rzadko obserwuje się erytrodermię [4].

Trudność w ustaleniu rozpoznania pomimo wykonania badania histopatologicznego wycinka ze zmiany polega na tym, że często obraz mikroskopowy długo jest niecharakterystyczny. W związku z tym należy rozważyć powtarzanie biopsji aż do momentu uzyskania diagnostycznego materiału i postawienia ostatecznej diagnozy [10]. Wycinek powinien zostać pobrany z miejsc najbardziej nacieczonych [17]. Warto pamiętać, że mnogość zmian skórnych możliwych do zaobserwowania w postaci folikulotropowej przekłada się na różnorodne obrazy mikroskopowe $\mathrm{w}$ badaniu histopatologicznym poszczególnych wycinków, a nawet tego samego wycinka [11]. W doniesieniach naukowych podkreśla się często rozróżnienie postaci folikulotropowej od klasycznego, najczęstszego wariantu MF. Wiąże się to $\mathrm{z}$ różnicami $\mathrm{w}$ rokowaniu oraz odpowiedzi na zastosowane leczenie, gdyż obie postaci odmiennie reagują na poszczególne metody terapeutyczne. Chodzi o skuteczność terapii ukierunkowanej na skórę w klasycznym MF i jej brak w postaci folikulotropowej [10]. Dlatego też $\mathrm{u}$ przedstawionego pacjenta $\mathrm{w}$ pierwszej kolejności zastosowano Re-PUVA, a następnie metotreksat z powodu niewielkiej poprawy.

Ważnym zagadnieniem jest związek MF z innymi nowotworami. W piśmiennictwie nie ma wielu 
cancer, and prostatic carcinoma as well as bladder cancer $[18,19]$. Factors that predispose MF patients to get subsequent neoplasms probably involve the following: elderly age, MF stage, and presence of lymphomatoid papulosis [18]. In the presented patient, after a year after diagnosing MF and 16 years after appearance of the first skin lesions, two lesions in his pancreas were revealed, however, it is not known how their course looked like and whether there is a connection to primary folliculotropic MF.

\section{CONCLUSIONS}

A folliculotropic type is a common variant of mycosis fungoides with a usually good prognosis and a 5 -year survival rate reaching about $80 \%$ [2]. The case of the presented patient emphasizes a possibility of occurrence of an atypical nature of lesions without head and neck skin involvement and with a concurrent neoplasm. It is of the essence to differentiate between the folliculotropic type and the classic MF as prognoses and therapies are different. Like in the classic type, it is recommended to repeat biopsies of skin lesions till the final diagnosis is established.

\section{CONFLICT OF INTEREST}

The authors declare no conflict of interest. doniesień na ten temat. U pacjentów z MF obserwuje się zwiększone ryzyko rozwoju chłoniaka Hodgkina, a także przewlekłej białaczki, raka płuc, gruczołu krokowego i pęcherza moczowego $[18,19]$. Prawdopodobnie czynnikami predysponującymi pacjentów z MF do zachorowania na kolejne nowotwory są: starszy wiek, stadium zaawansowania MF oraz obecność lymphomatoid papulosis [18]. U opisywanego chorego prawie rok po postawieniu diagnozy MF i 16 lat od wystąpienia pierwszych zmian skórnych wykryto dwie zmiany w trzustce, jednak nie wiadomo, jaki był ich późniejszy przebieg i czy miały jakikolwiek związek z pierwotnie występującym folikulotropowym MF.

\section{WNIOSKI}

Odmiana folikulotropowa jest częstym wariantem MF, zwykle o dobrym rokowaniu; 5-letnie przeżycie wynosi 80\% [2]. Przypadek przedstawionego pacjenta zwraca uwagę na możliwość występowania nietypowego obrazu zmian, bez zajęcia skóry głowy i szyi, oraz współistnienia nowotworu. Istotne jest rozróżnienie postaci folikulotropowej od klasycznej MF ze względu na odmienne rokowanie i postępowanie terapeutyczne. Podobnie jak w przypadku postaci klasycznej wskazane jest powtarzanie biopsji zmian skórnych do momentu postawienia ostatecznej diagnozy.

\section{KONFLIKT INTERESÓW}

Autorzy nie zgłaszają konfliktu interesów.

\section{References}

\section{Piśmiennictwo}

1. Sokołowska-Wojdyło M., Olek-Hrab K., Ruckemann-Dziurdzińska K.: Primary cutaneous lymphomas: diagnosis and treatment. Postep Derm Alergol 2015, 32, 368-383.

2. Sokołowska-Wojdyło M., Maj J., Robak E., Placek W., Wojas-Pelc A., Jankowska-Konsur A., et al.: Chłoniaki pierwotnie skórne - rekomendacje diagnostyczno-terapeutyczne Polskiego Towarzystwa Dermatologicznego. Przegl Dermatol 2017, 104, 243-268.

3. Bakar O., Seçkin D., Demirkesen C., Baykal C., Büyükbabani N.: Two clinically unusual cases of folliculotropic mycosis fungoides: one with and the other without syringotropism. Ann Dermatol 2014, 26, 385-391.

4. Muniesa C., Estrach T., Pujol R.M., Gallardo F., Garcia-Muret P., Climent J., et al.: Folliculotropic mycosis fungoides: clinicopathological features and outcome in a series of 20 cases. J Am Acad Dermatol 2010, 62, 418-426.

5. Malveira M.I.B., Pascoal G., Gamonal S.B.L., Castañon M.C.M.N.: Folliculotropic mycosis fungoides: challenging clinical, histopathological and immunohistochemical diagnosis. An Bras Dermatol 2017, 92, 73-75.

6. Terada T.: Mycosis fungoides in plaque stage with pronounced eosinophilic infiltration, folliculotropism, and concomitant invasive squamous cell carcinoma. Int J Clin Exp Pathol 2013, 6, 749-756.

7. Marschalkó M., Erôs N., Kontár O., Hidvégi B., Telek J., Hársing J., et al.: Folliculotropic mycosis fungoides: clinicopathological analysis of 17 patients. J Eur Acad Dermatol Venereol 2015, 29, 964-972.

8. Mantaka P., Helsing P., Gjersvik P., Bassarova A., Clausen O.P., Delabie J.: Clinical and histopathological features of folliculotropic mycosis fungoides: a Norwegian patient series. Acta Derm Venereol 2013, 93, 325-329.

9. Ahn C.S., ALSayyah A., Sangüeza O.P.: Mycosis fungoides: an updated review of clinicopathologic variants. Am J Dermatopathol 2014, 36, 933-948.

10. Gerami P., Rosen S., Kuzel T., Boone S.L., Guitart J.: Folliculotropic mycosis fungoides: an aggressive variant of cutaneous T-cell lymphoma. Arch Dermatol 2008, 144, 738-746.

11. Martínez-Escala M.E., González B.R., Guitart J.: Mycosis fungoides variants. Surg Pathol Clin 2014, 7, 169-189.

12. Dipak Mantri M., Khadke M.P., Ameet D.L., Rachita D.S.: Folliculotropic mycosis fungoides in an adolescent: a rare case. Indian J Dermatol 2016, 61, 467.

13. Bagot M.: Folliculotropic mycosis fungoides is a heterogenous group. Br J Dermatol 2017, 177, 17-18. 
14. van Santen S., Roach R.E., van Doorn R., Horváth B., Bruijn M.S., Sanders C.J., et al.: Clinical staging and prognostic factors in folliculotropic mycosis fungoides. JAMA Dermatol 2016, 152, 992-1000.

15. Brugière C., Karanian-Philippe M., Comoz F., Dompmartin A., Galateau-Sallé F., Verneuil L.: Two cases of aggressive nontumoral folliculotropic mycosis fungoides with visceral involvement. Br J Dermatol 2014, 171, 899-902.

16. Demirkesen C., Esirgen G., Engin B., Songur A., Oğuz O.: The clinical features and histopathologic patterns of folliculotropic mycosis fungoides in a series of 38 cases. J Cutan Pathol 2015, 42, 22-31.

17. van Doorn R., Scheffer E., Willemze R.: Follicular mycosis fungoides: a distinct disease entity with or without associated follicular mucinosis. Arch Dermatol 2002, 138, 191-198.

18. Väkevä L., Lipsanen T., Sintonen H., Ranki A.: Morbidity and causes of death in patients with cutaneous T-cell lymphoma in Finland. Acta Derm Venereol 2017, 97, 735-738.

19. Lewis D.J., Duvic M.: A possible association between mycosis fungoides and Muir-Torre syndrome: two disorders with microsatellite instability. JAAD Case Rep 2017, 3, 358-361.

Received: 6.02 .2018

Accepted: 3.12 .2018

Otrzymano: $6.02 .2018 \mathrm{r}$

Zaakceptowano: $3.12 .2018 \mathrm{r}$.

How to cite this article

Nowowiejska J., Baran A., Flisiak I.: Folliculotropic mycosis fungoides coexisting with pancreatic neuroendocrine tumour. Dermatol Rev/Przegl Dermatol 2018, 105, 746-752. DOI: https://doi.org/10.5114/dr.2018.80844. 